\title{
A USER'S GUIDE TO SASKATCHEWAN PARKS
}

MICHAEL and ANNA CLANCY. 2006. Discover Saskatchewan Series. R. Nilson, series editor. Canadian Plains Research Centre, Regina. 455 pages. Soft Cover. $17 \mathrm{~cm}$ by $24.5 \mathrm{~cm}$. Approx. 350 black and white photographs, 32 colour photographs, 6 maps. \$24.95 CDN. ISBN 978-0-88977-198-7.

A User's Guide to Saskatchewan Parks is the latest book in the Discover Saskatchewan Series published by the Canadian Plains Research Centre. With the sponsorship of Saskatchewan Regional Parks Association, Saskatchewan Heritage Foundation and Saskatchewan Parks Branch, the authors visited almost every regional, provincial and national park in Saskatchewan in the summers of 2004 and 2005 , and all active parks in these categories are covered in this book. The only parks not covered are those that lack camping facilities: parks run by the urban park authorities and national historic parks.

This book is an expanded update of a 1999 book on Saskatchewan Regional Parks by the same authors. ${ }^{1}$ This second edition differs from the first in that it contains updated information on active regional parks and includes all provincial parks and Grassland and Prince Albert national parks.

In the introduction, the authors describe the three types of parks discussed in the book, the purpose of the book and where to find key websites for current information on the parks. The authors want to interest readers in Saskatchewan's natural beauty, and have tried to create a useful tool for tourists and residents interested in the Province's parks. The book is written in conversational style, with the authors telling of their experiences in each park, including some amusing stories.

The book is divided by tourism region: southwest, southeast, eastcentral, west-central and northern. Each section begins with a map of the region. Each park entry contains information on location, dates/season and hours of business, entry fees, camping facilities and fees, sport facilities, available services in and near the park, and contact information. In most cases, provincial and national parks have longer entries than regional parks. Information on birding and hiking is sometimes in its own section but is sometimes located in the sports section, depending on the park entry. Each park entry has at least one black and white photograph of scenery, campsite, park sign, distinctive buildings, playgrounds or sport facilities. In the middle of the book, there is a series of colour photographs from 32 of the parks.

The final section contains recommendations for selected visits. It lists the parks with particular 
strengths in various service/activity categories. These categories include destination parks (with overall amenities for longer visits), wheelchair accessibility, hiking, birding, scenery, golf courses, baseball facilities, wilderness parks, cowboy poetry, rodeos, beaches, fishing, astronomy, and First Nations history and culture. This section is very helpful in designing one's travel and is one of the strengths of the book.

The index helps find park entries quickly and easily, and the map on the inside front cover shows the tourism regions and the distribution of parks. In the inside back cover, there is a two page summary table of services in the parks discussed in this book. Listed services and activities include camping/RV/tours, dump station, firewood, fast food, store (retail), phone, showers, modern washrooms, swimming, fishing, boat launch, golf, hiking/walking trails, laundromat, wheelchair access and fuel.

I think the book could have been improved by including all nonmunicipal parks, not just those with camping facilities, by using numbers on the tourism region maps to link directly to the entries on the parks shown on the map, and by the addition of a legend showing codes used in the list of park facilities on the inside back cover.

Overall this book is an excellent resource for tourists and Saskatchewan residents to learn more about activities, services and visitor costs associated with Saskatchewan Parks. It is also a good compliment for an earlier book on provincial and national historic sites. ${ }^{2}$ I highly recommend it to anyone interested in Saskatchewan parks.

1. CLANCY, M. and A. CLANCY. 1999. A User's Guide to Regional Parks. Discover Saskatchewan series. R. Nilson, series editor. Canadian Plains Research Center, Regina, SK.

2. LALONDE, M. and E. LACLARE . 1998. A Guide to Historic Sites. Discover Saskatchewan series. R. Nilson, series editor. Canadian Plains Research Center, Regina, SK.

Reviewed by Rob Warnock, 3603 White Bay, Regina, SK S4S 7C9. Email: warnockr@accesscomm.ca

"The color of bird's eggs is almost as varied as the plumage of the birds themselves. While plain white is common especially for those that nest in tree cavities or burrows, almost every other hue can be found on a bird egg somewhere or other. The pigment is applied during the egg's final passage down the oviduct and uterus. The color may be a uniform tone, like the smooth blue-green of a robin's egg, or it may be applied in random spots, scrawls, and blotches as the egg twists through the oviduct and past the pigment cells."

Scott Weidensaul, The Birder's Miscellany, p.51 